\title{
THE CONCEPT OF COMPREHENSIVE OFFER OF TOURISM AREA
}

AleKSANDER PANASIUK, ${ }^{1}$ GENKA RAFAILOVA ${ }^{2}$

RECEIVED

ACCEPTED

JEL

CLASSIFICATION

KEYWORDS

ABSTRACT
${ }^{1}$ University of Szczecin, POLAND

e-mail: aleksander.panasiuk@wzieu.pl

${ }^{2}$ University of Economics Varna, BULGARIA

e-mail: genka@rafailova.org

5 January 2017

10 February 2017

Z3, R10, R58

tourist product, tourist area, tourist destination, tourist offer

The issue of a tourism product causes a lot of controversy over its semantics and structure in both international and domestic literature on the subject. The problem mainly arises from using this term by representatives of many sciences and the industry. Moreover, the issue of a tourism product is constantly being developed in terms of both theoretical and pragmatic aspects. The objective of the study is to propose a concept of a comprehensive tourism offer of an area which is made up by particular components. The article is mainly theoretical; however, the discussed issues are of the utilitarian nature. They used the method of critical analysis of literature, logic operations and heuristics. Taken considerations are original. The result of the study is to design a concept of comprehensive offer tourist area.

\section{Introduction}

The issue of a tourism product causes a lot of controversy over its semantics and structure in both international and domestic literature on the subject. The problem mainly arises from using this term by representatives of many sciences and the industry. Moreover, the issue of a tourism product is constantly being developed in terms of both theoretical and pragmatic aspects. Primary categories determining a product in economics are goods (commodities) 
and services. Therefore, typical product categories on the tourism market are basic tourism products, especially tourism services. The category of a tourism product was also created in order to interpret processes taking place on the supply side of the market in tourism areas. Thus, a tourism product of an area was developed, also known as a territorial tourism product. A thorough analysis of features of the structure of a territorial tourism product has led to the interpretation of the term integrated (complex) tourism product that is a group of elements which it consists of and institutional activities. From the point of view of market relationships, a category that fully describes processes on the tourism market should be the term of a tourism offer of an area which, apart from subject and institutional elements, encompasses other elements of a traditional offer, including pricing and quality parameters, and terms of service. The objective of the study is to propose a concept of a comprehensive tourism offer of an area which is made up by particular components. The article is mainly theoretical; however, the discussed issues are of the utilitarian nature.

\section{Terpitorial tourism product}

A basic category creating tourism supply is a tourism product. From a broad perspective, it is a spatial and multifaceted category of a complex structure. A tourism product understood in such a way is developed by spatial entities (tourist destinations) and mainly by tourism regions, metropolitan and peripheral areas whose product is complex and includes a tourism area offer created by business entities (tourism enterprises) operating on the tourism market with the support of local authorities as well as tourism organizations. It is a product understood at a macro level which encompasses goods, services and other offers provided to consumers in an area of tourism reception (Mazurkiewicz, 2005, p. 83). A complex and spatial tourism product is described as a tourism product of a region (a tourism product of an area or a territorial tourism product). Such a product is developed at many levels and its structure consists of many diverse elements creating a coherent whole that is attractive for consumers of the tourism market.

A territorial tourism product can be interpreted in terms of two methodical perspectives (approaches):

- subjective - developed by tourist destinations with existing (material as well as non-material) elements of tourism potential of an area and then presented on the market as an offer of that area,

- psychological - resulting from tourists' ideas and expectations concerning a tourist destination and supported by the selection of material and non-material elements enabling creating an individual offer for a specific tourist.

The methodical perspective on a territorial tourism product has an objective nature. It is an offer of a tourist destination addressed to potential tourists as well as those using detailed elements of a tourism product offered by entities of the supply side of the tourism market. From this perspective, a tourism product can be interpreted as a complex product developed by many entities and consisting of many single elements which are partially similar, partially heterogenic, but always complementary (Hołderna-Mielcarek, 1998, p. 10). Each of these elements is functionally connected with others, even if they are created by various entities. This relation connects services of various entities from the supply system (tourism enterprises and tourists destinations) in a given area as none of them is able to fully satisfy tourism demand on their own.

Although a psychological approach to the interpretation of a tourism product is essential for every tourist as it enables selection of such components of a tourism offer of a place that satisfy their needs best, it is difficult to objectivise. The following definition reflects the meaning of a tourism product in terms of psychology: it is a product 
understood as a sum of impressions which a tourist receives during and after its consumption as well as a tourist's complex experience from the moment of leaving their permanent place of living until their return (Smith, 1994, pp. 583-586; Medlik, Middleton, 1973; Żemła, 2000, p. 27).

Both methodical perspectives permeate and complement each other as they are developed on the basis of the same elements of the tourism product structure. The issue of the asymmetry of information on product elements between service providers and consumers can be problematic (Panasiuk, 2016, pp. 752-764). Quite a significant part of elements of the tourism product structure is unknown to individual tourists. However, there are such elements of a territorial tourism product that are only in the field of interests of individual tourists and those who manage a product are not aware of existence of such elements, thus tourists' reasons for coming to a specific destination.

The mentioned perspectives on a territorial tourism product determine each other and influence its development in the long term. Individual tourists' behaviours (tourist reasons) with time may arouse interest of tourist destination entities in terms of creating a new product or adding new elements to an existing one.

The sum of defined tourism products of a place from the psychological perspective is not a tourism product understood from the subjective perspective. However, some elements of a tourism product considered from the subjective perspective may not be noticed by tourists. Due to the difficulty of objectivising the interpretation of elements of the tourism product structure from the psychological perspective, further deliberations will concern a tourism product seen from the subjective perspective.

Therefore, when interpreting the structure of a territorial tourism product, one should start with the concept by V.T.C. Middleton who distinguished five main components of a tourism product. These are:

- destination attractions and environment,

- destination infrastructure and services,

- destination accessibility,

- destination image,

- price (Middleton, 1996, p. 89).

This structure of a tourism product of an area is widely referred to in the literature. However, it is difficult to fully agree with this concept. A tourism product should be definitely considered as an offer that is the object of supply and gives grounds for a sale and purchase transaction. Then, a destination image should not be treated as part of an offer created by a tourist destination. The notion of image should be understood as an idea about a provider and their offer existing in their direct surroundings, mainly among consumers. It includes a set of positive associations evoked by the reception of presented information on a provider (their name, trademark, offered product). This idea does not have to coincide with the reality and it can be only a subjective image of a provider or their offer. Therefore, image reflects the identity perception (Wiktor, 2001, p. 214). A tourist destination can create image and influence tourists in order to strengthen and improve it, however, the image of a tourism area is not an integral element of an offer as it is not the object of transaction. Furthermore, it should be emphasised that it can change over time and be different among specific elements of the market, but also diverse in terms of specific tourism forms and types which can be found in a tourism area.

Isolating a price as an element of the structure of a territorial tourism product should be also subject to criticism. A price is a separate element of the tourism market supply structure and a category describing a product and indicating practical values of this product. Similarly to a tourism area image, a price is not also the object of transaction. Transaction takes place on the basis of it. 
One should also critically refer to isolating destination accessibility in the structure of a territorial tourism product proposed by V.T.C. Middleton. It is an element that is a derivative of destination infrastructure and services. This element concerns infrastructure and transport services which have already been isolated in this system and is a function of transport system in terms of passenger operations in tourism (Zioło, Rachwał, 2012; Milewski, 2012 , pp. 161-171).

A popularised method of isolating elements of the structure of a territorial tourism product in Polish literature on the subject also has other flaws in terms of details. From the point of view of presentation of the territorial tourism product structure, a more adequate method of isolating elements of the structure of a territorial tourism product should be presented. A territorial tourism product is formed of tourism goods and facilities as well as tourism services. Tourism goods and facilities, which are a dominant objective of tourist travels, include such elements as (Panasiuk, 2014a, pp. 111-122):

- basic (tourism values, tourist attractions),

- complementary (tourist facilities).

The second element of the structure of a territorial tourism product is tourism services which, in other words, are products (Rogoziński, 2012, p. 12-13) created by tourism enterprises (mainly individual services, material goods or their sets called service packages) and offered on the market for a payment as well as free of charge (e.g. booking, information). The range of supply in this case is determined by capital, organizational resources and goals of tourism enterprises. Therefore, a tourism service as a product can be examined at a micro level, as basic tourism products (every single service), or at a macro level as an integral component of a territorial tourism product. These services can be classified into three groups:

a) basic - services that satisfy tourists' needs, result directly from the tourism facilities functioning and are mainly provided by tourism enterprises, that is services connected with accommodation, catering, transport and with tourism forms and types (e.g. health resort services, conference and congress services),

b) complementary - services that enable taking benefits from tourism values and tourist attractions, are provided by both tourism enterprises and tourist destinations, that is services connected with information, inbound tourism organization, guiding, tourist equipment rental, car rental, some services of travel agencies (Konieczna-Domańska, 1994, p. 22) (e.g. booking, sales of tickets for tourist attractions),

c) paratourist - services provided by entities of indirect tourism economy, that is banking and insurance, trade and crafts, postal and telecommunication services, local infrastructure (public).

\section{Integrated tourism product}

To make a territorial tourism product actively satisfy tourism demand, it is necessary that activities of specific entities being providers on the tourism market integrate and focus on particular elements of the tourism product structure. In other words, if a tourism product should be treated in an integrated way, it is necessary to undertake institutional activities.

Thus a possibility of offering a tourism product requires support of entities that create it. Influencing the target markets requires that entities offering the product cooperate. Both public and commercial entities are responsible for the components of a tourism product. The domain of influence of public entities is, in particular, values and tourist attractions as well as some tourism facilities (especially transport and accommodation base) and some tourism 
services (e.g. in the field of tourist information). Commercial entities are responsible for the functioning of remaining types of tourism facilities and provision of most services. However, the division is conventional to a large extent as, for example, services in tourist information are provided by public entities (mainly local and regional authorities) and tourist values (attractions) can be created by commercial entities.

An integrated tourism product should be understood as a tourism area offer developed by entities providing services on the tourism market, both commercial (hotels, restaurants, carriers, salesmen, operators of cultural, entertainment, recreational and sport facilities, etc.) and public ones (tourist destinations, i.e. local authority bodies), as well as tourism organizations which help to establish cooperation between direct service providers and local authority bodies (e.g. regional tourism organizations and possibly tourism clusters) (Panasiuk, 2014b, pp. 55-56).

A prerequisite for development of an integrated tourism product is not only the fact that elements determining existence of a tourism product from the area perspective (supply object) are present in a tourism area and individual activities of tourism service providers take place (supply subjects: tourism enterprises, local authorities, organizations as well as tourist destinations in a broad sense), but mainly that these entities create conditions for cooperation and specific actions supporting the influence on a territorial tourism product and its components (protection of values, investments, maintenance of tourism facilities, tourism offer development).

\section{Tourism offer}

The notion of an offer is an economic term connected with the functioning of a market economy which is used both in economic theory and practice in terms of economic law as well as finance of business entities. The issue of interpretation of the term offer does not appear in scientific publications on market functioning. The offer is created by entities of the market supply side and is addressed to mass as well as individual consumers.

The term offer should be understood comprehensively as a set of elements, which create it, that presents seller's supply capabilities, is a proposal to sell and an incentive to buy products and gives grounds for transaction (purchase-sale agreement) (Dębski, 2006, p. 184; Wojciechowska, Florczak, 2005, pp. 97-107). In marketing, the concept of an offer combines elements connected with a product and price (Pindelski, 2010, pp. 11-19).

A tourism offer as a set of elements that create it can be considered, as in the case of the analysis of issues concerning tourism supply, from two perspectives:

- narrow - concerning tourism services provided by tourism enterprises on the market,

- broad - concerning a territorial tourism product.

Regardless of the perspective adopted, a tourism offer consists of the following elements:

- an entity making an offer (provider),

- a place of an offer,

- a product (from the structural perspective),

- a product price

- product quality (practical values which it is characterised by),

- an offer period,

- terms of sale (payment, delivery, guarantee, possibility of withdrawal from an agreement),

- provider's responsibility. 


\section{Comprehensive offer of tourism area}

The way a tourism destination offer is presented on the market does not constitute an offer in a traditional way which has effects resulting from civil law. Considering a territorial tourism product from two perspectives - subjective (created by a tourism destination) and psychological (arising from tourists' ideas and expectations in a place of tourism reception) - determines the specification of elements of a tourism destination offer. Basic elements of a tourism destination offer constitute the tourism product structure, i.e. values, tourism facilities and services. Complementary elements of the offer include mainly:

- accommodation base and additional services (including paratourist ones) - their use depends on tourism forms,

- events - they are part of tourist attractions, but they are not permanent, but can extend an offer seasonally; however, if a given event is a main or only attraction in a given destination, then it should be treated as a basic element of an offer,

- tourist information - available in a place of tourism reception as well as in an online form (a destination's website) as an element enabling the combination of remaining elements of an offer into a whole,

- public services - provided by municipal services (Kożuch, Kożuch, 2008, pp. 19-35); they create conditions for a safe stay for tourists in a place of tourism reception and are connected with maintaining it clean and orderly, and good conditions for a stay.

Generally, the issue of interpretation of a price of a territorial tourism product should be treated indirectly. Tax revenues which go to local authorities budgets are just some percentage of taxes paid to the government budget. Nevertheless, revenues from direct and indirect taxes, which have been generated in a tourism area, partially fund local budgets and determine local development. Taking account of the fact that tourists in tourism areas are prone to purchase more and more expensively that in their permanent places of living, buy products that satisfy their needs connected only with their stay and which they do not buy normally, and, in addition, prices in tourism areas (especially in those characterised by a high level of seasonality) are higher, tax revenues going to local budgets should be unquestionably considered as revenues resulting from the sale of a territorial tourism product. These revenues determine volume of sale so, analysed in economic terms, they directly correspond to a price. A special tax and a price element is a local fee (health resort fee) paid by tourists (patients) in some tourist destinations. Revenues from local fees directly fund local budgets, similarly to a property tax (paid by tourism enterprises). With respect to foreign inbound tourism, a price instrument at the level of a tourist destination which is a country means also visa fees and possible customs fees connected with import or export of certain products.

Quality elements of an offer result directly from the assessment of elements included in research on tourism area attractiveness. Taking a time criterion, especially in areas of intense tourism (recreational towns of a seasonal nature or huge urban agglomerations) into consideration, a tourism offer period, which is a tourism product of an area, concerns preparations made by tourist destinations for an influx of a large group of tourists. It pertains to works connected with adapting local infrastructure to the needs of tourist influx (communication, water and sewage services, cleaning) and drawing up the so-called calendar of events which, in addition, influence interest of potential tourists in a given place.

Elements of a tourism area offer which concern terms of sale have the least specific form. As there is no formal relationship between a tourist destination and a tourist arising from purchase and sale transaction, issues in this respect are exclusively conventional (relative). Payments are made during the purchase of goods and services in 
a tourism area by means of taxes included in a price and settlement of amounts for a local fee and accommodation. The issue of delivery concerns time that a tourist spends in a tourism area and benefits from elements of an offer, i.e. values, attractions and tourism facilities. Potential guarantees can pertain to claims related to health or life threatening conditions or for damage to property if such situations have happened and arisen out of acts or omissions of relevant services in a place of tourism reception (for example during a mass event, a tourist would suffer due to the fact that the site has not been properly secured). It can be claimed that tourists can be unsatisfied with their stay due to weather conditions or other events connected with acts of nature (flood, earthquake, hurricane, etc.), or also a socio-political situation (demonstrations, civil war), however, it cannot be a basis for claiming any damages. Tourists can only shorten their stay or resign from coming to a place of tourism reception. In this respect, withdrawal from an agreement is also restricted in terms of offers of tourism enterprises.

One should also refer to the interpretation of an offer from the psychological perspective on a territorial tourism product which is more difficult as product elements are individually selected by consumers. However, from the point of view of tourists who spend time in a tourism area and purchase goods and services as well as benefit from tourism values and facilities, this way they create a certain set of elements which becomes for them an area product and determines the structure of a tourist destination offer addressed individually to every tourist.

Summing up, it should be noted that a tourism enterprise offer bears the hallmarks of a traditional market offer and can produce any legal effects arising out of obligations of the parties related to the purchase and sale of a product - a tourism offer. A tourism destination offer should not be considered as an equivalent to a tourism product of an area. The offer structure, that is a territorial tourism product, is created by an analogous range of elements as in terms of an offer of tourism enterprises. An offer understood this way determines market potential of a tourism area, is presented on the market and is subject to processes of consumption and competition. It is not a fully developed offer as many entities creating it put forward their partial offers, some elements that create it (e.g. tourism values) are not a direct object of trade and, moreover, although a tourist destination as an entity develops an offer, it does not carry out any formal market transactions with purchasers (tourist consumers).

A tourism offer presented in the above way is a basis for defining a special role of a consumer (a tourist) on the tourism market in relation to an offer of tourism enterprises and destinations. A consumer has a double role in the market. Firstly, he is a consumer of services offered by tourism enterprises. Due to that, a formal legal relationship is created that arises from a purchase-sale agreement for tourism services. Secondly, he is a consumer (a tourist) of a tourist destination offer consisting of many elements which create the structure of a territorial tourism product. No special formal relationship is created between a tourist and a destination, but a tourist benefits from elements of an offer.

\section{Conclusions}

A comprehensive offer of a tourism area can become a next category that describes relationships on the tourism market in practice. A condition for that is a transition from understanding a territorial tourism product solely from the subjective perspective to integration of this perspective with activities of entities (institutions). Only integrated activities of entities of tourism economy in a tourism area can serve as the basis for creating a comprehensive tourism offer. Therefore, it should be emphasised that many activities of local authorities in terms of developing tourism products (e.g. related to infrastructure or local events) were not of the market nature. In the EU financial perspective 2007-2013, funds were expended for tourism products and their promotion, not taking account 
of institutional support and offer commercialisation. Tourism 'pseudo-products', which do not generate revenues for tourism enterprises and/or local authority bodies, were created.

\section{References}

Dębski, M. (2006). Marka obszarów turystycznych jako element rozwoju turystyki w regionie. Studia i Prace Kolegium Zarządzania, 181. Hołderna-Mielcarek, B. (1998). Regionalizacja produktu turystycznego. Rynek Turystyczny, 12.

Konieczna-Domańska, A. (1994). Usługi pośrednictwa i organizacji w rozwoju rynku turystycznego. Warszawa: SGH.

Kożuch, B. \& Kożuch, A. (2008). Istota usług publicznych. Współczesne Zarządzanie, 1.

Mazurkiewicz, L. (2005). Produkt turystyczny w ujęciu marketingu terytorialnego. In: K. Pieńkoś (ed.), Konkurencyjność produktu turystycznego. Warszawa: Wyższa Szkoła Ekonomiczna.

Medlik, S. \& Middleton, V.T.C. (1973). Product formulation in tourism. Tourism and Marketing, 13.

Middleton, V.T.C. (1996). Marketing w turystyce. Warszawa: Polska Agencja Promocji Turystyki.

Milewski, D. (2012). Postulaty przewozowe jako cechy jakości przewozów turystycznych. Prace Naukowe Uniwersytetu Ekonomicznego we Wrocławiu, 258.

Panasiuk, A. (2016). Asymetria informacji na rynku turystycznym. Ekonomista, 5.

Panasiuk, A. (2014a). Rynek turystyczny. Studium strukturalne. Warszawa: Difin.

Panasiuk, A. (2014b). Selected issues of management of regional tourist product. Scientific Journal of Service Management, 12.

Pindelski, M. (2010). Sprzedaż a marketing. Zeszyty Naukowe Uniwersytetu Ekonomicznego w Poznaniu, 135.

Rogoziński, K. (2012). Definicja usługi i to, co poniżej. Ekonomiczne Problemy Usług, 95.

Smith, S. (1994), The Tourism Product. Annals of Tourism Research, 2.

Wiktor, J.W. (2001). Promocja, System komunikacji przedsiębiorstwa z rynkiem. Warszawa: Wydawnictwo Naukowe PWN.

Wojciechowska, J. \& Florczak, D. (2005). Oferta agroturystyczna łódzkich biur podróży -próba definicji pojęcia. Problemy Turystyki, $1-2$.

Zioło, Z. \& Rachwał, T. (ed.) (2012). Innowacyjność usług turystycznych w układach przestrzennych. Annales Universitatis Paedagogicae Cracoviensis, Studia Geographica III. Kraków: Wydawnictwo Naukowe Uniwersytetu Pedagogicznego w Krakowie.

Żemła, M. (2000). Produkt turystyczny - ujęcie podmiotowe. Problemy Turystyki, 1-2.

Cite this article aS: Panasiuk, A., Rafailova, G. (2017). The concept of comprehensive offer of tourism area. European Journal of Service Management, 21 (1), 37-44. DOI: 10.18276/ejsm.2017.21-05. 